\title{
A Theology of the Septuagint?
}

\section{JOHANN COOK (STELLENBOSCH UNIVERSITY)}

\begin{abstract}
This contribution to the Festschrift for Sakkie Spangenberg addresses the question of whether it is appropriate and even possible to formulate "the/a theology of the Septuagint." To be sure, this author (Cook) has endeavoured to formulate "theologies" of LXX Proverbs and the Old Greek of Job as case studies. However, there is no consensus that it is appropriate or even viable to do so. There are broadly speaking two groupings in this regard: the minimalists and the maximalists. It is the aim of this paper to take cognisance of this uncertainty and to address diverse perspectives on this issue. After a brief introduction, the minimalists will be introduced, followed by a consideration of the maximalists.
\end{abstract}

KEYWORDS: Septuagint; Proverbs; Job; theology of LXX.

\section{A INTRODUCTION}

Scholars differ on the question as to whether it is possible or even appropriate to formulate the/a theology of the Septuagint, as is done with the Hebrew Bible (HB). There are broadly speaking two theoretical positions in this regard. The first is a minimalist view held by, among others, the Septuagint scholars Albert Pietersma and Raija Sollamo, ${ }^{1}$ who are more sceptical about this possibility. However there are some scholars (Martin Rösel, Joachim Schaper, etc.) who adopt more of a maximalist approach. As will become clear, however, the picture is more complex. But it has also become clear that many of these scholars do not differ so much on the question of whether a theology (depending on definitions) of the LXX is viable, but rather on how this could in fact be achieved. As a matter of fact, most of the differences between these approaches seem to be rooted in questions of methodology. This applies to

* Article submitted: 18/02/2017; peer-reviewed: 26/05/2017; accepted: 5/06/2017. Johann Cook, “A Theology of the Septuagint?" Old Testament Essays 30/2 (2017): 265-282, doi: http://dx.doi.org/10.17159/2312-3621/2017/v30n2a5

1 Cf. Albert Pietersma, "Exegesis in the Septuagint: Possibilities and Limits (The Psalter as a Case in Point)," in Septuagint Research: Issues and Challenges in the Study of the Greek Jewish Scriptures, ed. Wolfgang Kraus and R. Glenn Wooden, SCS 53 (Atlanta: SBL, 2006), 333-45, and Raija Sollamo, "Translation Technique as a Method," in Translating a Translation the LXX and its Modern Translations in the Context of Early Judaism, ed. Hans Ausloos, et al., BETL 213 (Leuven: Uitgeverij Peeters, 2008), 6. 
more than just the question of formulating a theology of the LXX, but also hermeneutical studies in general. ${ }^{2}$

\section{B THE MINIMALISTS}

For the sake of a broader perspective I commence with the ground-breaking research of Michael Fox on the Septuagint version of Proverbs. I deliberately place him with this grouping since he has done much research on the books of Proverbs, he, inter alia, thinks that the translator of Proverbs in fact rendered his parent text faithfully. According to him, LXX Proverbs is "primarily a translation, one aiming at a faithful representation of the Hebrew, and it is best understood in terms of that goal." ${ }^{3} \mathrm{He}$ is also of the opinion that it is possible to utilise this rendering in order to reconstruct Semitic Vorlagen.

\section{The Hebrew Bible: A Critical Edition (HBCE) ${ }^{4}$}

The Hebrew Bible: A Critical Edition (HBCE) represents a novel paradigm for a critical (eclectic) edition of the HB. ${ }^{5}$ According to Hendel, this edition "combines the best (or earliest) readings from various sources into a critical text ..."6 As is well known, this is a different concept from that represented by diplomatic editions. The aim of the HBCE is "to restore, to the extent possible, the manuscript that was the latest common ancestor of all the extant witnesses."7 This is a rather difficult task and raises many questions. How will the common ancestor be determined? What is the archetype? Is it different from the Ur-text? Be that as it may, it is a legitimate and overdue project, especially in the wake of the discovered and published Dead Sea Scrolls, as well as other recent developments in the Septuagint. The challenge with this project lies not with the why it should be done, but with the how - the methodology. ${ }^{8}$

2 See the presidential address of Johann Cook at the IOSOT 2016 congress held at the University of Stellenbosch, 4-9 September 2016, entitled "Interpreting the Septuagint," to be published as Johann Cook, "Interpreting the Septuagint," in Congress Volume Stellenbosch 2016, ed. Christl M. Maier, et al., VTSup (Leiden: Brill, 2017), forthcoming.

3 Michael Fox, Proverbs 1-9: A New Translation with Introduction and Commentary, AB 18a (New York: Doubleday, 2000), 361.

4 See the review of this book by Cook, which will appear in JSS in 2018.

5 Michael Fox, משלי Proverbs: An Eclectic Edition with Introduction and Textual Commentary, HBCE 1 (Atlanta: SBL Press, 2015).

6 Ronald Hendel, "Series Foreword," in משלי Proverbs: An Eclectic Edition with Introduction and Textual Commentary, by Michael Fox, HBCE 1 (Atlanta: SBL Press), ix.

7 Hendel, "Series Foreword," ix.

8 The necessary background to this project may be found at the following website: www.hbceonline.org. 
Michael Fox has been constructively involved in the scientific discipline of textual criticism for a long time. So he is aware of the pitfalls awaiting the text critic who addresses the books (note the plural) of Proverbs. "In the case of Proverbs one cannot reasonably aim to recover the full archetype. The book is too multiplex, the resources too scanty." His ultimate goal is evidently "to reconstruct the corrected archetypes of biblical books." 10

Fox puts all his cards on the table:

I wish to be clear that the text I have produced, however successful, never had physical existence. It is a construct. It can be defined as the proto-M as it should have been, the text the authors and editors wanted us to read. ${ }^{11}$

Exactly the same problem pertains to the Göttingen edition of the Septuaginta Unternehmen.

Fox has a sound feel for textual criticism; in his own words: "it must be emphasised, my reconstructions and literary-critical proposals are based on exegesis." 12 It is clear that Fox knows this text inside out. He was responsible for the Anchor Bible's commentary. That Fox adopts a nuanced position is clear from the following statement:

An emendation must finally stand on its own. Support from the ancient translations and even other Hebrew texts can at best show that a variant existed, not that it is valid. Even a Hebrew variant may be wrong. ${ }^{13}$

Fox does not readily resort to conjecture. Fox and I differ on various issues, one being the difference in the order of chapters towards the end of LXX Proverbs. I have already dealt exhaustively with the issue of the macrolevel differences between LXX and, for example, MT. ${ }^{14} \mathrm{I}$ am of the opinion that the different order of chapters compared to MT and the other major textual witnesses is the result of the translator's intervention. Fox ${ }^{15}$ agrees with Tov

9 Fox, משלי Proverbs, 2.

10 Fox, משלי Proverbs, 2.

11 Fox, משלי Proverbs, 4-5.

12 Fox, משלי Proverbs, 6.

13 Fox, משלי Proverbs, 81.

14 Johann Cook, "The Greek of Proverbs: Evidence of a Recensionally Deviating Hebrew Text?" in Emanuel: Studies in Hebrew Bible, Septuagint, and Dead Sea Scrolls in Honor of Emanuel Tov, ed. Shalom M. Paul, et al., (Leiden: Brill, 2003), 605-18.

15 Fox, Proverbs 1-9, 361. See also James K. Aitken and Lorenzo Cuppi, "Proverbs," in The T\&T Clark Companion to the Septuagint, ed. James K. Aitken (London: Bloomsbury, 2015), 348. 
about a different recension of Proverbs. To me it seems as an argument from silence, since the Greek text is the sole witness.

The heart of the monograph, the reconstructed text of LXX Proverbs, is found in ch. 5 and is based upon his preceding theoretical reflections. Some issues are problematic. The most conspicuous discrepancy is that the Hebrew text is pointed. The translator in all probability had an unvocalized text in front of him.

I made a pilot study of chs. 1 and 8 of LXX Proverbs and it struck me how few parentheses (indications of retroversions) were used in these chapters. In Prov 1 parentheses are used only in connection with כְשָאוֹ in v. 27. It was also surprising to me in how few places Fox in fact changed the Hebrew (Masoretic) text. I remain sceptical about some of Fox's conclusions. My problem remains that the text-critical value of LXX Proverbs is low. ${ }^{16}$ Its translation technique is so free that I for one would not be willing to attempt to reconstruct its Semitic Vorlage consistently. ${ }^{17}$ Having said that, I have to admit that Fox has made some brilliant intuitive retroversions, the result of his firsthand knowledge of the text.

I now move onto other interpretations of the LXX.

\section{Messianism in the Septuagint}

One example of other interpretations is Messianism in the Septuagint. A congress was organised at Leuven on this issue. ${ }^{18}$ The groups mentioned above were evident there as well. As point of departure Knibb used the research of Coppens on this topic. ${ }^{19}$ It is immediately clear that Coppens belongs in the maximalist group. Pietersma, on the other hand, belongs with the minimalists.

16 Johann Cook, "The Text-Critical Value of the Septuagint of Proverbs," in Seeking out the Wisdom of the Ancients: Essays in Honor of Michael V. Fox on the Occasion of his Sixty-Fifth Birthday, ed. Ronald L. Troxel, Kelvin G. Friebel, and Dennis R. Magary (Winona Lake: Eisenbrauns, 2005), 407-419.

17 Cook, "Greek of Proverbs."

18 Michael Knibb, "Problems and Issues," in The Septuagint and Messianism, ed. Michael Knibb, BETL 195 (Leuven: Leuven University Press / Uitgevery Peeters, 2006), 1-19.

19 Cf. Joseph Coppens, Le messianisme royal: Ses origins, son development, son accomplissement, LD 54 (Paris: Les Éditions du Cerf, 1968). See the views of Johan Lust, "Messianism and Septuagint," in Messianism and the Septuagint Collected Essays, ed. Johan Lust, BETL 178 (Leuven: University Press / Uitgeverij Peeters, 2004), 9-40 in this regard. 
He is especially critical of Schaper's interpretation of Eschatology in the Psalms. $^{20}$

\section{$3 \quad$ A Theology of the Septuagint}

Another example is the question of whether it is in order to formulate a theology of the Septuagint. Again the two groupings are clear to see. Not everybody is positive about the possibility of formulating a theology of the LXX, since there is a clear minimalist view in this respect. ${ }^{21}$ McLay seems to be opposed to such an endeavour. ${ }^{22}$ He formulated three issues as criticism:

(i) A theology of/in (sic) the Septuagint is not limited to the OG text;

(ii) It is not limited to the differences between the Greek texts and the presumed Semitic source texts;

(iii) Theology of/in the LXX may be examined and described with the same legitimacy and use the same basic principles as a theology of the OT/HB or NT.

Alex Douglas, who speaks about the limitations in the writing of a theology in this regard, is another example. ${ }^{23}$ A final example is Dafni who in one context seems to agree "dass die Siebzig primär nur Übersetzer waren und nicht Theologen."24

\section{Greek Cultural (i.e. Philosophical) Ideas in the Septuagint}

A third issue is the question of the amount of Greek cultural (i.e. philosophical) ideas that are found in the Septuagint. Again scholars have different views. Cook should be placed in the minimalist group in this context. ${ }^{25}$ In connection with other aspects he in fact can be placed with the maximalists. As far as the

20 Pietersma, "Exegesis in the Septuagint," 33-45. See also the evaluation by Knibb, "Problems and Issues," 1-19.

21 Pietersma, "Exegesis in the Septuagint," 33-35.

22 Timothy McLay, "Why Not a Theology of the Septuagint?" in Die Septuaginta: Texte, Theologien, Einflüsse, ed. Wolfgang Kraus, Martin Karrer, and Martin Meiser, WUNT 252 (Tübingen: Siebeck, 2010), 616.

23 Alex Douglas, "Limitations to Writing a Theology of the Septuagint," JSCS 45 (2012): 104-117.

24 Cf. Evangelia Dafni, "Theologie der Sprache der Septuaginta im Horizont des Altgriechischen Schrifttums und Denkens," JSem 18 (2009): 444. It must be said that her view is more complex when she discusses "mögliche Grundtypen für die Komposition einer Theologie der Septuaginta" on the next page.

25 Johann Cook, "The Septuagint of Genesis: Text and/or Interpretation?" in Studies in the Book of Genesis: Literature, Redaction, and History, ed. André Wénin, BETL 155 (Leuven: University Press, 2001), 315-329. 
book of Genesis is concerned, some scholars find evidence of platonic ideas, especially in chs. 1 and 2, whereas others hold a different view.

There is a significant pattern of harmonisation of the Septuagint version of Genesis ch. 1. There are two positions in this regard: a different parent text, or the result of the translator's work. I recently changed my mind about the view that it was the translator who was responsible for this harmonisation. ${ }^{26}$ Rösel, as I did earlier, seems to presuppose that there is a direct relationship between form and content. ${ }^{27}$ In the final analysis he finds traces of platonic influence in LXX Gen 1. The two loaded concepts, aópatos and

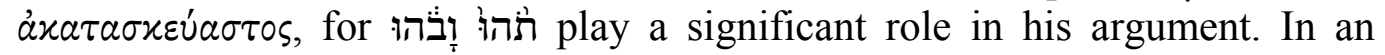
article entitled "A 'Genetic' Commentary on the Septuagint of Genesis," Hiebert concurs with Rösel on this issue. ${ }^{28} \mathrm{He}$ writes: "Another possible explanation for the choice of áópatos as counterpart for is that it constitutes a reflection of Platonic ideas and cosmological terminology." He then quotes from Plato Tim 50c-d and 51a-b.

Van der Horst reacts strongly to the idea of Platonic cosmological influence in this Greek verse. ${ }^{29}$ In his own words, he finds it is rather "far fetched." 30 David Runia ${ }^{31}$ holds a similar view, as can be gleaned from the following comment:

Rösel $^{32}$ has recently revived the idea that the LXX translators of Genesis themselves were influenced by Plato's Timaeus, but in this case the hypothesis lacks all plausibility. It is Philo who sees the connection. ${ }^{33}$

Van der Horst takes a cue from the Greek lexicon and more specifically

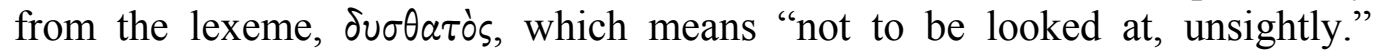
According to Van der Horst, this nuance fits in with the second adjective,

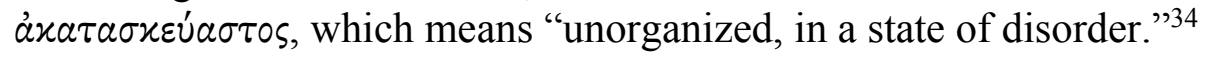

26 See Johann Cook, "Genesis 1 in the Septuagint as an Example of the Problem: Text and Tradition," JNSL 10 (1982): 25-36, for the original view.

27 Martin Rösel, Übersetzung als Vollendung der Auslegung: Studien zur GenesisSeptuaginta, BZAW 223 (Berlin: de Gruyter, 1994).

28 Robert J. V. Hiebert, "A 'Genetic' Commentary on the Septuagint of Genesis," JSCS 46 (2013): 19-36.

29 Pieter W. van der Horst, "Was the Earth 'Invisible'? A Note on áópatos in Genesis 1:2 LXX," JSCS 48 (2015): 5-7.

30 Van der Horst, "Was the Earth?" 6.

31 David Runia, Philo of Alexandria and the Timeaus of Plato (Leiden: Brill, 1996).

32 Rösel, Übersetzung, 82.

33 David Runia, Philo of Alexandria on the Creation of the Cosmos according to Moses (Leiden: Brill, 2001), 165, italics added.

34 Van der Horst, "Was the Earth?" 6. 
The most recent contribution on this issue is by Michael van der Meer. ${ }^{35}$ He has an innovative approach in that he explores the papyri dating from the 3rd-1st century BCE in Egypt in analysing Gen 2 v. 7. He addresses three issues:

(i) Does the Old Greek translation of Gen 2:7 mark a turning-point, a transformation in Israelite and early Jewish anthropology?

(ii) If so, was the Old Greek translation a deliberate departure from the ancient Israelite concepts, and if so,

(iii) Was the Old Greek translator influenced by Greek philosophical concepts?

His answer to the third question is negative. He puts forward a number of arguments to support his view. First, he introduces novel material into the discussion, the papyri. Secondly, he follows Van der Leeuw, ${ }^{36}$ who interprets

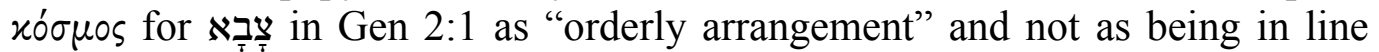
with Plato's cosmogony, as Rösel does. ${ }^{37}$ Thirdly, he suggests an intermediate approach to the study of the Septuagint by way of the vast corpus of Greek documentary papyri from Ptolemaic and early Roman Egypt. ${ }^{38}$ He conducts a

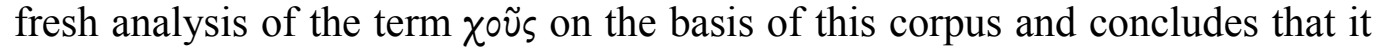
does not mean "dust," but "a heap of clay." Finally, he concludes: "In lxx Gen 2:7 there is no dualism between body and soul. In fact, it is only through the combination of matter ( $\chi \cup \tilde{\varsigma} \varsigma$ ) and spirit ( $\left.\pi \nu \circ \eta^{\prime}\right)$ that a $\psi \cup \chi \eta \dot{~ c o m e s ~ i n t o ~ b e i n g . " ~} 39$ Thus he finds no Greek philosophical, Platonic ideas in the first chapters of LXX Genesis.

35 Michael N. Van der Meer, "Anthropology in the Ancient Greek Versions of Gen 2:7," in Dust of the Ground and Breath of Life (Gen 2:7): The Problem of a Dualistic Anthropology in Early Judaism and Christianity, ed. Jacques T. A. G. M. van Ruiten and George H. van Kooten (Leiden: Brill, 2016), 56.

36 Theo A. W. Van der Louw, Transformations in the Septuagint: Towards an Interaction of Septuagint Studies and Translation Studies, CBET 47 (Leuven: University Press / Uitgeverij Peeters, 2007).

37 Van der Meer, "Anthropology," 40.

38 Van der Meer, "Anthropology," 51.

39 Van der Meer, "Anthropology," 56. 
272 Cook, “A Theology of the Septuagint?" OTE 30/2 (2017): 265-282

\section{THE MAXIMALISTS}

\section{Creation in Genesis}

Rösel offers the most exhaustive interpretation of the creational passages. He deals with the LXX an sich and he adopts a comprehensive methodological approach. ${ }^{40} \mathrm{He}$ proffers a number of arguments in support of his view.

(i) Genesis 1:1 he interprets as a creatio ex nihilo. Hence there is no room for Greek philosophical interpretation: "alles kommt auf die Wirkung Gottes an." ${ }^{41}$

(ii) He does, nevertheless, find it strange that the translator used the verb $\pi 0$ เ $\omega$ for that the translator in fact took a cue from Plato's Timaeus. ${ }^{42}$ There the verb $\pi \circ \varepsilon^{\prime} \omega$ is used for the God and father (the demiurge) who creates the "Weltseele" and the "Weltkörper" and $\pi \lambda \alpha \dot{\sigma} \sigma \omega$ for the subordinate helpers.

(iii) Rösel follows Philo of Alexandria in his Platonic interpretation that Gen 1 is a description of the ideal world and Gen 2 of the real world.

(iv) The second verse is also interpreted in a Platonic vein by Rösel. The

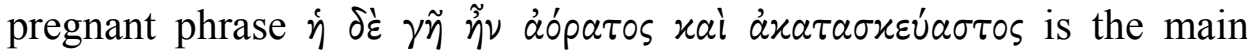
object of analysis and he opts for Philo's interpretation, which is found in his work On the creation of the world (De opificio mundi).

(v) Rösel's next piece of evidence in Gen 1 he finds in the systematic

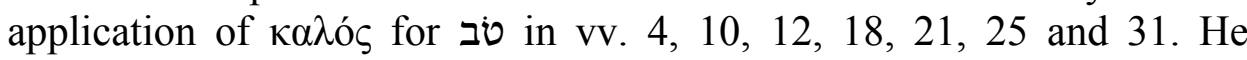
connects this to the world of Greek philosophy, where the Greek concept xalós is an indication of order and symmetry.

(vi) Part of the motivation for finding Platonic influence in Gen 1 is the assumed harmonising tendency of the translator, which Rösel finds in this chapter.

(vii) Rösel goes further to interpret v. 26 in the LXX in a Platonic vein. The

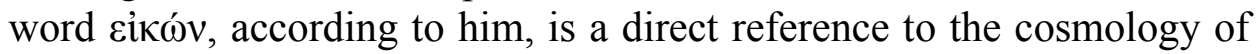
Plato.

(viii) Rösel also interprets Gen 2 in a Platonic vein. The first verse includes

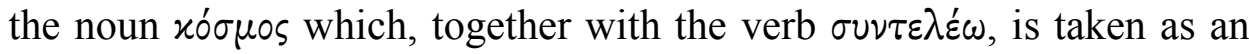

40 What follows is based on a paper presented at the Bijbelse Studie Dagen held in 1998, and published as Cook, "Septuagint of Genesis," 315-329. I obtained permission of Peeters publishing house to use the article.

41 Rösel, Übersetzung, 29.

42 Rösel, Übersetzung, 30. 
indication of the order and symmetry that is inherent in the Timaeus (92c).

There are a number of problems with this Platonic interpretation of the creation stories in LXX Genesis. Firstly, the translator presents a faithful rendering of these chapters. In most cases one therefore has to make deductions

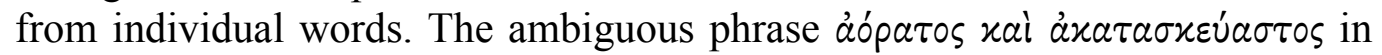
Gen 1:2 is a case in point. These words are practically hapax legomena; the first is also used in Isa 45:3 and 2 Macc 9:5. Moreover, even though the concept of the equivalent invisible and unformed is used in the Timaeus, the Greek words do not appear together in the treatise itself. The nearest possible parallel is Plato's reference to a $<<$ mother and receptacle $>>$, which he called "a kind

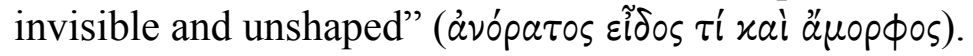

Another problem involves Plato's view of the creator and pre-existent matter. It is clear that God was considered by Plato to be an artificer (demiurge) who had formed the cosmos from pre-existent matter. He used different expressions to define his concept of matter. It is called chora-space (Tim. 52b), that place where everything came into being. It was, also according to Plato,

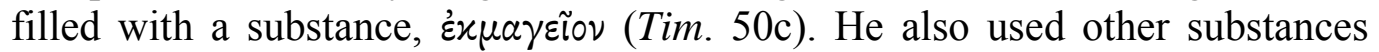
such as gold, wax and oil metaphorically to describe the matter used by the artificer in the "mother and receptacle," the chora-space.

It is difficult to determine what the nature of this matter was for Plato. According to Aristotle, Plato actually identified matter and space (Phys. 209 b). Zeller held the view that matter in a platonic sense was nothing else but space. ${ }^{43}$ Guthrie argued that Plato meant more than space with the concept of chora, namely a "matrix, stuff without property." 44 According to him, this chaos was taken over by the artificer. Happ also takes chora as a Materieprinzip and not space, which accounts for the fact that it is devoid of all properties. ${ }^{45}$ Be that as it may, Plato believed in the pre-existence of matter which was used to realise the material world. However, Rösel argues that the Greek translator, even though he followed Platonic thought, did not understand Gen 1 in this way.

A further problem I have with Rösel's interpretation is the way in which he applies perspectives from Philo of Alexandria. Firstly, there is a huge time gap between the origin of the Septuagint and this Hellenistic-Jewish author.

43 Eduard Zeller, Die Philosophie der Griechen in ihrer geschichtlichen Entwickelung, vol. 3/2 (Leipzig: O.R. Reisland, 1905), 147.

44 William K. C. Guthrie, The Later Plato and the Academy, vol. 5 of A History of the Greek Philosophy, ed. William K. C. Guthrie (Cambridge: Cambridge University Press, 1978), 268.

45 Heinz Happ, Studien zum aristotelischen Materie-Begriff (Berlin: De Gruyter, 1971), 101. 
Secondly, Philo not only used Platonic ideas in his description of the creation, but he incorporated aspects from other philosophical systems as well. The interpreter is left with a bewildering compilation of perspectives (Platonic, Stoic and especially Middle Platonism). This is especially true of Philo's understanding of pre-existent matter. To complicate matters further, he applied his view to the biblical (Greek) version of creation (Gen 1 and 2). In this regard, however, he is ambiguous. On the one hand, he interprets the first five verses in Genesis (day one) in terms of the incorporeal world of Plato; on the other hand, he takes Gen 1 as a description of the incorporeal world in the Platonic sense of the word, with Gen 2 as the realisation of the material world. This interpretation he based on the Septuagint of Gen 2:9 and 17. The addition of the adverb $\varepsilon^{\tau} \tau$ in these verses is seen as a direct reference back to the ideal creation in Gen 1 (Leg. 1, 56). In the LXX these additions also relate these two chapters, but not in the Platonic sense. Gen 2 refers to matters that have already been described in three passages in Gen 1 . The first is v. 7, where the formation of man is described. There is a difference between Gen 1 and 2 in that two different verbs are used. This fundamental difference between the "men" of the two chapters is underlined by the addition of $\delta \nu$ है $\pi \lambda \alpha \sigma \varepsilon \nu$ in Gen 2:15. The second and third passages in Gen 2, which are related to Gen 1, are indeed indicated by means of the adverb हैं $\tau$ in Gen 2:9 and 17. This has nothing to do with Platonism, but is the result of internal harmonisation (contra Rösel?).

In the final analysis I am left with the uneasy sense that Rösel has too easily closed the time and cultural gap between LXX Genesis and Plato, as well as Philo of Alexandria. I am therefore not totally convinced by his position. My scepticism is based upon my own research into LXX Genesis, but even more so on my research on the Septuagint version of Proverbs. ${ }^{46}$

Evangelia Dafni is probably the most outspoken propagator of correspondences between the Semitic world of Gen 1-11, the Hellenistic world and the classical world of Plato. In an article on Plato's Symposium and the LXX her point of departure is that

Plato's teachings have never lost their dominance in the intellectual scene or the general education system of the Hellenistic world. Therefore one cannot seriously dispute the encounter of the Old Testamental thoughts with Plato's thoughts. The crucial question is: Did the Septuagint (LXX) manage to absorb linguistic forms from Plato's work without at the same time absorbing basic Platonic, philosophical concepts? The LXX translators wanted to proclaim the Old Testament belief to the Hellenistic world via the Greek language. At the same time they wanted to prevent that polytheistic concepts were introduced into the world of the Old Testament via the language. The LXX has thus adopted the refined forms of

46 Johann Cook, "Greek Philosophy and the Septuagint," JNSL 24 (1998): 177-191. 
expression of Plato's work, which represents the first and only completely handed-down philosophic work of the antique Greeks, and changed them as necessary. The Platonic linguistic forms in the LXX can be seen as a type of Old Testamental meta-language of great theological importance. This meta-language was created due to philosophic reflection about linguistic and mental constructs of the Old Testament. ${ }^{47}$

Two further questions are discussed by her.

Waren die Übersetzter der hebräischen Schriften ins Griechische von altgriechischen Autoren inspiriert, oder folgten sie bloß manchmal dem Wortlaut altgriechischer Texte? ${ }^{48}$

She operates eclectically with the hypothesis that the author(s) of Gen 1-11, in the Greek and the Hebrew, were aware of Plato's individual treatises and utilised them in the construction/translation of Gen 1-11. It must be said that she holds a variety positions in this regard. On the one hand, as becomes clear from the quote above, she propagates a direct encounter between OT and Platonic thought. On the other hand, she seems uncertain, for, in comparing Plato's treatise Phaedros with Gen 2:23, she comes to the conclusion

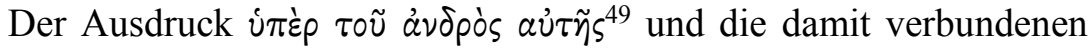

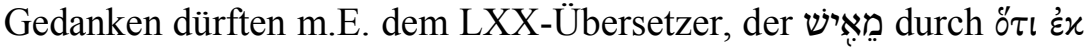

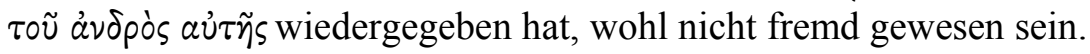
Doch dies bedeutet nicht etwa den Einfluss Platos auf die LXX. Vielmehr ist es ein deutlicher Hinweis auf algemein menschlichen Gedankengut. $^{50}$

In the light of my arguments above, I remain sceptical. I shall deal more exhaustively with this position in another context.

47 Evangelia Dafni, "Genesis 1-11 und Platos Symposion: Überlegungen zum Austausch von hebräischem und griechischem Sprach- und Gedankengut in der Klassik und im Hellenismus," OTE 19 (2006): 584.

48 Dafni, "Theologie der Sprache," (2009): 443.

49 This phrase in fact appears in Plato, Symp. 179b-c.

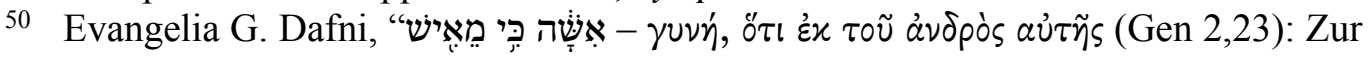
Anthropologie von Genesis 1-11," in Studies in the Book of Genesis: Literature, Redaction and History, ed. André Wénin, BETL 155 (Leuven: University Press, 2001), 584. 


\section{The Formulation of a Theology of the Septuagint}

Scholars have been engaged in "exegetical" activity on the LXX for a long time. Zaharias Frankel and Abraham Geiger are early examples. ${ }^{51}$ Seeligmann was one of the first scholars to address the issue of the exegesis of the LXX systematically. ${ }^{52}$ Ziegler, ${ }^{53}$ according to Rösel, ${ }^{54}$ was the first scholar to explicitly express the intention to write a theology of the Septuagint.

Definitions of what should be understood by the concept of "theology" in the LXX vary. The term "exegesis" is used by many scholars. Bertram ${ }^{55}$ refers to "theological exegesis" in this regard. Emanuel Tov uses various terms. ${ }^{56} \mathrm{He}$ distinguishes between linguistic and contextual exegesis, and argues that theological exegesis occurs primarily in the more freely rendered books, such as Isaiah, Daniel, Job and Proverbs. ${ }^{57}$ Aejmeleaus has her own view of theology ${ }^{58}$ in the Septuagint: "'Theologie' verstehe ich in diesem Zusammenhang im weitesten Sinn als einen Sammelbegriff für religiöse oder theologische Überzeugungen." ${ }^{59}$ D'Hamonville finds religious and theological concepts in LXX Proverbs. ${ }^{60}$ Dafni also addressed this issue. ${ }^{61}$ In this regard

51 Zacharias Frankel, Über den Einfluss der palästinischen Exegese auf die alexandrinische Hermeneutik (Leipzig: Bei Fr. Chr. Wilh. Vogel, 1851) and Abraham Geiger, Urschrift und Übersetzung der Bibel in ihrer Abhängigkeit von der innern Entwickelung des Judentums, 2nd ed. (Breslau: Verlag von Julius Hainaner, 1857).

52 Isaac L. Seeligmann, The Septuagint Version of Isaiah: A Discussion of its Problems, MVEOL 9 (Leiden: Brill, 1948).

53 Joseph Ziegler, Die Septuaginta: Erbe und Auftrag, WUni 33 (Würzburg: Würzburg Univertsität, 1962).

54 Martin Rösel, "Eine Theologie der Septuaginta? Präzisierungen und Pointierungen," in Septuagintastudien. Untersuchungen zu Text und Theologie der Septuaginta, ed. Frank Ueberschaer, WUNT (Tübingen: Mohr, Siebeck, 2017), forthcoming.

55 Georg Bertram, "Die Umdeutung altorientalischer Lebenweisheit in der griechischen Übersetzung des AT," ZAW 13 (1936): 153-167. According to Rösel, "Eine Theologie der Septuaginta?" he coined the concept "Septuaginta-Frömmigkeit."

56 Emanuel Tov, The Text-Critical Use of the Septuagint (Leiden: Brill, 1981), 82.

57 Emanuel Tov, "Theologically Motivated Exegesis Embedded in the Septuagint," in The Greek and Hebrew Bible: Collected Essays on the Septuagint, ed. Emanuel Tov, VTSup 72 (Leiden: Brill, 1999), 258.

58 Anneli Aejmelaeus, "Von Sprache zur Theologie: Methodologische Überlegungen zur Theologie der Septuaginta," in The Septuagint and Messianism, ed. Michael A. Knibb, BETL 195 (Leuven: Leuven University Press / Uitgeverij Peeters, 2006), 23.

59 "Also, Wenn es sich aber um Theologie der Septuaginta-Übersetzer handelt, sind ihre sprachlichen Äusserungen alles, was wir haben," (Aejmelaeus, "Von Sprache zur Theologie," 22).

60 David-Marc D'Hamonville, Les Proverbes: Traduction du texte grec de la Septante, LBA 17 (Paris: Les Éditions du Cerf, 2001), 135.

61 Evangelia Dafni, “Theologie der Sprache der Septuaginta,” TZ 58 (2002): 322. 
she talks about "Eine Theologie der Sprache ist also vor allem und grundsätzlich aus dem Wortwahl der Septuaginta zu suchen." ${ }^{22}$ See also Dafni. ${ }^{63}$

The most comprehensive position on the possibility of writing a theology of the Septuagint has been put forward by Martin Rösel. ${ }^{64}$ What is clear to me is that "theology" is to be located in the way any given translator in fact renders his parent text. It is in the differences between the source text and the target text that interpretation becomes evident. ${ }^{65}$ This interpretation could be understood as exegesis or theology.

In a contribution presented in Wuppertal in 2015, Martin Rösel recently provided helpful background to this development. ${ }^{66} \mathrm{He}$ sees the theology of the LXX as a subjective genitive that should be understood as an implicit theology of the Greek translation. As such its reflective nature is characteristic. He also takes seriously Pietersma's distinction between text-production and textreception. He, moreover, finds that there are elements of a genitivus objectivus when the Septuagint is taken as a unity. In this regard he mentions the Wisdom of Solomon and Judith as examples. As criterion for the implicit theology he refers to its above-mentioned reflective character. He accepts Schmidt's view of "das der Systematisierung vorgegebener Aussagen." 67 Again he explains by means of examples, in this case the terminology for altars to which I refer to in footnote 78 .

Martin Rösel deems the following issues of critical significance in endeavouring to formulate a theology of the Septuagint:

(i) That the LXX can no longer be seen as a unity from which one can simply place prooftexts next to another;

(ii) That a theology of the LXX must be diachronically orientated. Thus the historical context is critical;

62 Dafni, "Theologie der Sprache," (2002): 324.

63 Dafni, "Theologie der Sprache," (2009): 435.

64 Martin Rösel, "Towards a 'Theology' of the Septuagint," in Septuagint Research: Issues and Challenges in the Study of the Greek Jewish Scriptures, ed. Wolfgang Kraus and R. Glenn Wooden, SCS 53 (Atlanta: SBL, 2006), 239-252. See also Johann Cook, "Towards the Formulation of a Theology of the Septuagint," in Congress Volume Ljubljana 2007, ed. André Lemaire, VTSup 133 (Leiden: Brill, 2010), 621-640.

65 Dafni, “Theologie der Sprache," (2002): 324.

66 I thank Prof. Rösel for sending this paper to me. See Rösel, "Eine Theologie?" (forthcoming).

67 He mentions, "Es gibt im späten Alten Testament selber eine Tendenz zur Systematik“" (Rösel, "Eine Theologie?" forthcoming). 
278 Cook, “A Theology of the Septuagint?" OTE 30/2 (2017): 265-282

(iii) He suggests the systematising of topoi such as nomos, messianism, etcetera;

(iv) Finally, he finds it acceptable to take into account the later revisions, including the NT.

Cook is another example of this grouping. ${ }^{68}$ According to him, it is important to take into account a number of aspects when attempting to formulate a theology of the Septuagint.

Firstly, the diversity of the Septuagint should be reckoned with. The OG is not a unity. Each translated unit should be dealt with independently. Secondly, such a theology should only be formulated in conjunction with the OG text. The reception of the LXX should be dealt with as a separate aspect. ${ }^{69}$

Thirdly, this endeavour must be diachronic in nature. Hence, confronting the reality of diversity, it must be acknowledged that there are many theologies and it is possible that each book will present a different perspective depending, inter alia, on its context and time frame. In the light of the above, I think the individual book should act as a guideline as to how "LXX theologies" should be formulated. As a sine qua non I suggest that the diversity of the books of the Septuagint should be honoured. This is underscored by Rösel's first conclusion ${ }^{70}$ that:

a "Theology" of the Septuagint cannot be based on the levelling of differences among the individual books or the specific profiles of the translators for the sake of a common edifice of ideas. ${ }^{71}$

Another issue that will clearly have to be taken seriously is that a "Theology" (theologies?) of the LXX should be more than, and hence different from, what is formulated in a theology of the HB. ${ }^{72}$ Since the LXX is translational literature, and inherently represents an interpretation of these Semitic texts, such a theology should be comparative in nature, as suggested by Joosten. ${ }^{73}$

68 Cook, "Towards the Formulation," 621-640.

69 However, see Rösel, "Eine Theologie?" forthcoming, who takes later revisions into account.

70 Rösel, "Towards a 'Theology," 240.

71 Rösel, "Towards a "Theology,", 240. In another context he speaks about "implizite Theologie der griechischen Übersetzungen" in this regard. See Rösel, "Eine Theologie?" forthcoming.

72 For the purposes of the current paper the NT is left out of consideration. The focus is the $\mathrm{OG}$.

73 Jan Joosten, "Une théologie de la Septante? Réflexions méthodologiques sur l'interprétation de la version grecque," RTP 132 (2000): 33. 
I am, however, not certain that it is desirable to systematise the various theological perspectives to be located in each individual book at this stage. My suggestion is that each pericope of each book should be analysed on the basis of an exegetical commentary ${ }^{74}$ and then interpreted.

Another issue is whether no distinction should be made between the OG and Hebrew Vorlagen, as suggested by Douglas. ${ }^{75}$ But Rösel (forthcoming) is correct to argue that such distinct readings should be preserved.

In the final analysis I would therefore argue that it is possible and even necessary to formulate a theology, or more correctly, theologies of the individual Septuagintal books. ${ }^{76}$ In this regard an appropriate methodology is essential. ${ }^{77}$ Hence the OG texts should be the object of this formulation. There should also be no uncertainty about the fact that "theological/exegetical" perspectives occur throughout the Septuagint (OG). Rösel ${ }^{78}$ and Schaper have provided a multitude of examples. The problem, however, remains how to interpret these perspectives. I would therefore suggest that formulating theologies of the Septuagint should be the next step, that is after the current phase of the writing of exegetical commentaries ${ }^{79}$ has been completed.

\section{CONCLUSION}

The placing of approaches into maximalist and minimalist groupings applies only broadly and the distinction is used only as a heuristic tool. This author, for one, might be placed in both groupings. What is clear is that the time has arrived for hermeneutical research in Septuagintal studies. One of the issues to be addressed is the formulation of a theology (or theologies) of the Septuagint.

74 Dirk Büchner, “A Commentary on Septuagint Leviticus 19:11-15," in Septuagint, Sages, and Scripture Studies in Honour of Johann Cook, ed. Randall X. Gauthier, Gideon R. Kotzé and Gert J. Steyn, VTSup 172 (Leiden: Brill, 2016), 68-83.

75 Douglas, "Limitations," 104-117.

76 Dafni, "Theologie der Sprache," (2009): 445 suggests "mögliche Grundtypen für die Komposition einer Theologie der Septuaginta."

77 Cook, "Interpreting the Septuagint," forthcoming.

78 His suggestions concerning the difference in terminology used in the LXX to describe the true cult of Israel contrasted to the pagan cults of the Umwelt (Rösel, "Towards a 'Theology,"” 240) are convincing.

79 See Johann Cook, "Between Text and Interpretation: An Exegetical Commentary on LXX Proverbs," in XV Congress of the International Organization for Septuagint and Cognate Studies Munich, 2013, ed. Wolfgang Kraus, Michaël van der Meer, and Martin Meiser, SCS 64 (Atlanta: SBL, 2016), 649-666. It must be conceded that this is perhaps a too idealistic position. 


\section{BIBLIOGRAPHY}

Aejmelaeus, Anneli. "Von Sprache zur Theologie: Methodologische Überlegungen zur Theologie der Septuaginta." Pages 21-48 in The Septuagint and Messianism. Edited by Michael A. Knibb. BETL 195. Leuven: Leuven University Press / Uitgeverij Peeters, 2006.

Aitken, James K. and Lorenzo Cuppi. "Proverbs.” Pages 341-355 in The T\&T Clark Companion to the Septuagint. Edited by James K. Aitken. London:

Bloomsbury, 2015.

Bertram, Georg. "Die religiöse Umdeutung altorientalischer Lebenweisheit in der griechischen Übersetzung des AT." ZAW 13 (1936): 153-167.

Büchner, Dirk. “A Commentary on Septuagint Leviticus 19:11-15.” Pages 66-83 in Septuagint, Sages, and Scripture Studies in Honour of Johann Cook. Edited by Randall X. Gauthier, Gideon R. Kotzé and Gert J. Steyn. VTSup 172. Leiden: Brill, 2016.

Cook, Johann. "Genesis 1 in the Septuagint as an Example of the Problem: Text and Tradition." JNSL 10 (1982): 25-36. . "Greek Philosophy and the Septuagint." JNSL 24/1 (1998): 177-191. . "The Septuagint of Genesis: Text and/or Interpretation?" Pages 315-329 in The Book of Genesis. Edited by André Wénin. BETL 155. Leuven: University Press, 2001.

. "The Greek of Proverbs: Evidence of a Recensionally Deviating Hebrew Text?” Pages 605-18 in Emanuel: Studies in Hebrew Bible, Septuagint, and Dead Sea Scrolls in Honor of Emanuel Tov. Edited by Shalom M. Paul, Robert A. Kraft, Lawrence H. Schiffman, and Weston W. Fields. Leiden: Brill, 2003. . "The Text-Critical Value of the Septuagint of Proverbs." Pages 407-419 in Seeking out the Wisdom of the Ancients: Essays in Honor of Michael V. Fox on the Occasion of his Sixty-Fifth Birthday. Edited by Ronald L. Troxel, Kelvin G. Friebel, and Dennis R. Magary. Winona Lake: Eisenbrauns, 2005. . "Towards the Formulation of a Theology of the Septuagint." Pages 621-640 in Congress Volume Ljubljana 2007. Edited by André Lemaire. VTSup 133. Leiden: Brill, 2010. . "Towards a Theology of the Old Greek Text of Job." Pages 353-362 in A Pillar of Cloud to Guide: Text-critical, Redactional, and Linguistic Perspectives on the Old Testament in Honour of Marc Vervenne. Edited by Hans Ausloos and Benedicte Lemmelijn. BETL 269. Leuven: University Press, 2014. ."A Theology of the Greek Version of Proverbs." HTS 71 (2015). Art. \# 2971. 11 pages. Doi: http://dx.doi.org/10.4102/hts.v71i1.2971. . "Between Text and Interpretation: An Exegetical Commentary on LXX Proverbs." Pages 649-666 in XV Congress of the International Organization for Septuagint and Cognate Studies Munich, 2013. Edited by Wolfgang Kraus, Michaël van der Meer, and Martin Meiser. SCS 64. Atlanta: SBL, 2016. . "Interpreting the Septuagint." Forthcoming in Congress Volume Stellenbosch 2016. Edited by Christl M. Maier, Louis C. Jonker and Gideon R. Kotze. VTSup 177. Leiden: Brill, forthcoming.

Coppens, Joseph. Le messianisme royal: Ses origins, son development, son accomplissement. LD 54. Paris: Les Éditions du Cerf, 1968. 


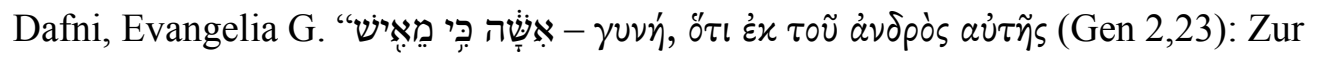
Anthropologie von Genesis 1-11." Pages 569-584 in Studies in the Book of Genesis: Literature, Redaction and History. Edited by André Wénin. BETL 155. Leuven: University Press, 2001. ."Theologie der Sprache der Septuaginta." TZ 58 (2002): 315-328.

. "Genesis 1-11 und Platos Symposion: Überlegungen zum Austausch von hebräischem und griechischem Sprach- und Gedankengut in der Klassik und im Hellenismus." OTE 19/2 (2006): 582-634.

. "Theologie der Sprache der Septuaginta im Horizont des Altgriechischen Schrifttums und Denkens." JSem 18/2 (2009): 434-457.

D'Hamonville, David-Marc. Les Proverbes: Traduction du texte grec de la Septante. LBA 17. Paris: Les Éditions du Cerf, 2000.

Douglas, Alex. "Limitations to Writing a Theology of the Septuagint." JSCS 45 (2012): 104-117.

Fox, Michael V. Proverbs 1-9: A New Translation with Introduction and Commentary. AB 18a. New York: Doubleday, 2000. משלי Proverbs: An Eclectic Edition with Introduction and Textual Commentary. HBCE 1. Atlanta: SBL Press, 2015.

Frankel, Zacharias. Über den Einfluss der palästinischen Exegese auf die alexandrinische Hermeneutik. Leipzig: Bei Fr. Chr. Wilh. Vogel, 1851.

Geiger, Abraham. Urschrift und Übersetzung der Bibel in ihrer Abhängigkeit von der innern Entwickelung des Judentums. 2nd ed. Breslau: Verlag von Julius Hainaner, 1857.

Guthrie, William K. C. The Later Plato and the Academy. Vol. 5 of A History of the Greek Philosophy. Edited by William K. C. Guthrie. Cambridge: Cambridge University Press, 1978.

Happ, Heinz. Studien zum aristotelischen Materie-Begriff. Berlin: De Gruyter, 1971.

Hendel, Ronald. "Series Foreword." Pages ix-x in משלי Proverbs: An Eclectic Edition with Introduction and Textual Commentary. By Michael Fox. HBCE 1. Atlanta: SBL Press.

Hiebert, Robert J. V. “A 'Genetic' Commentary on the Septuagint of Genesis.” JSCS 46 (2013): 19-36.

Joosten, Jan. "Une théologie de la Septante? Réflexions méthodologiques sur l'interprétation de la version grecque." RTP 132 (2000): 31-46.

Knibb, Michael A., ed. The Septuagint and Messianism. BETL 195. Leuven: Leuven University Press / Uitgevery Peeters, 2006. . "The Septuagint and Messianism: Problems and Issues." Pages 1-19 in The Septuagint and Messianism. Edited by Michael Knibb. BETL 195. Leuven: Leuven University Press / Uitgevery Peeters, 2006.

Lust, Johan. "Messianism and Septuagint." Pages 9-40 in Messianism and the Septuagint Collected Essays. Edited by Johan Lust. BETL 178. Leuven: University Press / Uitgeverij Peeters, 2004.

McLay, Timothy. "Why Not a Theology of the Septuagint?" Pages 607-620 in Die Septuaginta: Texte, Theologien, Einflüsse. Edited by Wolfgang Kraus, Martin Karrer, and Martin Meiser. WUNT 252. Tübingen: Siebeck, 2010.

Pietersma, Albert. "Exegesis in the Septuagint: Possibilities and Limits (The Psalter as a Case in Point)." Pages 33-45 in Septuagint Research: Issues and Challenges 
282 Cook, “A Theology of the Septuagint?” OTE 30/2 (2017): 265-282

in the Study of the Greek Jewish Scriptures. Edited by Wolfgang Kraus and R. Glenn Wooden. SCS 53. Atlanta: SBL, 2006.

Rösel, Martin. Übersetzung als Vollendung der Auslegung: Studien zur GenesisSeptuaginta. BZAW 223. Berlin: de Gruyter, 1994.

."Towards a 'Theology' of the Septuagint." Pages 239-252 in Septuagint Research: Issues and Challenges in the Study of the Greek Jewish Scriptures. Edited by Wolfgang Kraus and R. Glenn Wooden. SCS 53. Atlanta: SBL, 2006. . "Eine Theologie der Septuaginta? Präzisierungen und Pointierungen."

Forthcoming in Septuagintastudien: Untersuchungen zu Text und Theologie der Septuaginta. Edited by Frank Ueberschaer. WUNT. Tübingen: Mohr Siebeck, 2017.

Runia, David. Philo of Alexandria and the Timeaus of Plato. Leiden: Brill, 1996. . Philo of Alexandria on the Creation of the Cosmos according to Moses. Leiden: Brill, 2001.

Schaper, Joachim. "Messianism in the Septuagint of Isaiah and Messianic Intertextuality in the Greek Bible." Pages 371-380 in The Septuagint and Messianism. Edited by Michael Knibb. BETL 195. Leuven: Uitgeverij Peeters, 2006.

Seeligmann, Isaac L. The Septuagint Version of Isaiah: A Discussion of its Problems. MVEOL 9. Leiden: Brill, 1948.

Sollamo, Raya. "Translation Technique as a Method." Pages 35-41 in Translating a Translation the LXX and its Modern Translations in the Context of Early Judaism. Edited by Hans Ausloos, Johann Cook, F. Garcia Martinez, Benedicte Lemmelijn, and Marc Vervenne. BETL 213. Leuven: Uitgeverij Peeters, 2008.

Tov, Emanuel. The Text-Critical Use of the Septuagint. Leiden: Brill, 1981.

. "Theologically Motivated Exegesis Embedded in the Septuagint." Pages 257-269 in The Greek and Hebrew Bible: Collected Essays on the Septuagint. Edited by Emanuel Tov. VTSup 72. Leiden: Brill, 1999.

Van der Horst, Pieter W. "Was the Earth 'Invisible'? A Note on áópatos in Genesis 1:2 LXX." JSCS 48 (2015): 5-7.

Van der Louw, Theo A. W. Transformations in the Septuagint: Towards an Interaction of Septuagint Studies and Translation Studies. CBET 47. Leuven: University Press / Uitgeverij Peeters, 2007.

Van der Meer, Michael N. "Anthropology in the Ancient Greek Versions of Gen 2:7." Pages 36-57 in Dust of the Ground and Breath of Life (Gen 2:7): The Problem of a Dualistic Anthropology in Early Judaism and Christianity." Edited by Jacques T. A. G. M. van Ruiten and George H. van Kooten. Leiden: Brill, 2016.

Zeller, Eduard. Die Philosophie der Griechen in ihrer geschichtlichen Entwickelung. Vol. 3/2. Leipzig: O.R. Reisland, 1905.

Ziegler, Joseph. Die Septuaginta: Erbe und Auftrag. WUni 33. Würzburg: Würzburg Universität, 1962

Prof. Johann Cook, Department of Ancient Studies, University of Stellenbosch. E-mail:cook@sun.ac.za. 